\title{
Measurement of Vehicle Air Conditioning Pull-Down Period
}

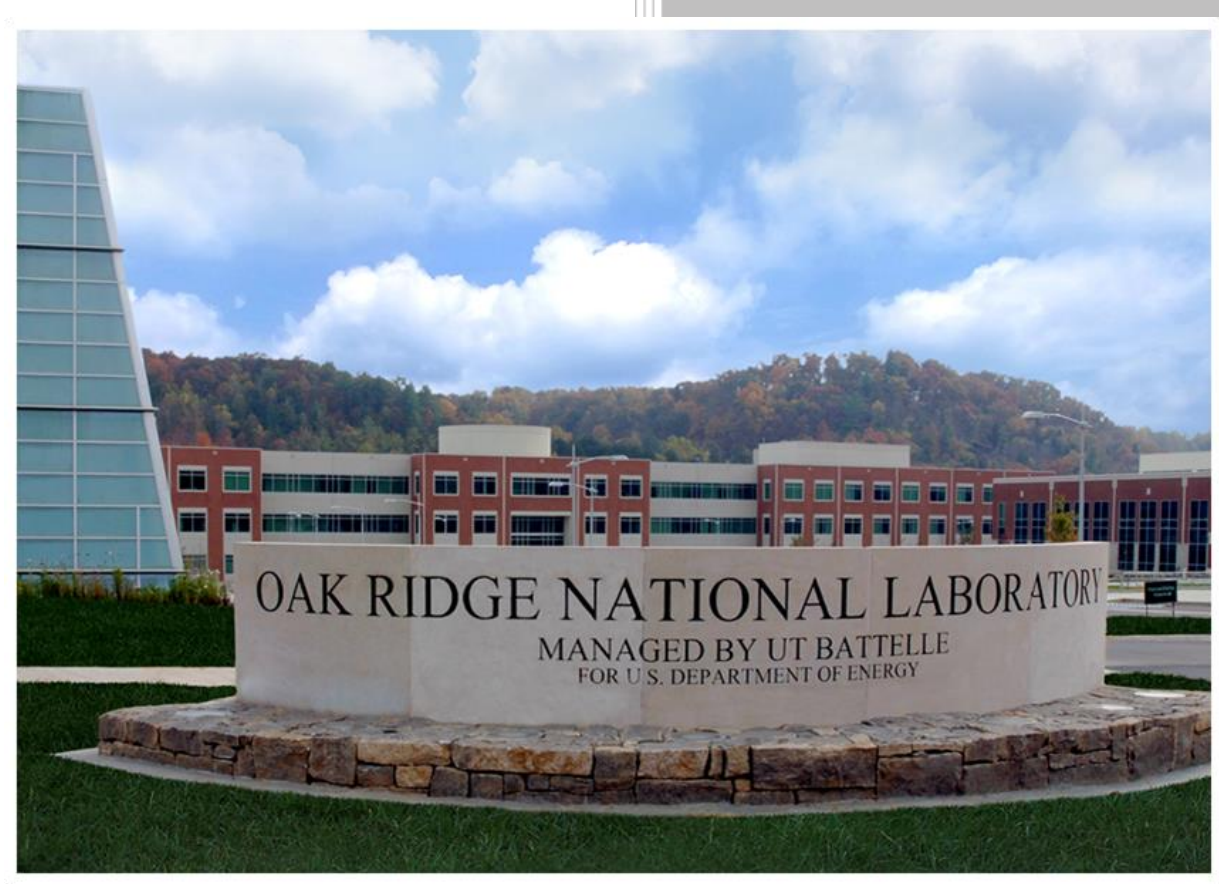

Approved for public release. Distribution is unlimited.

John F. Thomas

Shean P. Huff

Larry G. Moore

Brian $\mathrm{H}$. West

July 2016 


\title{
DOCUMENT AVAILABILITY
}

Reports produced after January 1, 1996, are generally available free via US Department of Energy (DOE) SciTech Connect.

\section{Website http://www.osti.gov/scitech/}

Reports produced before January 1, 1996, may be purchased by members of the public from the following source:

\author{
National Technical Information Service \\ 5285 Port Royal Road \\ Springfield, VA 22161 \\ Telephone 703-605-6000 (1-800-553-6847) \\ TDD 703-487-4639 \\ Fax 703-605-6900 \\ E-mail info@ntis.gov \\ Website http://www.ntis.gov/help/ordermethods.aspx
}

Reports are available to DOE employees, DOE contractors, Energy Technology Data Exchange representatives, and International Nuclear Information System representatives from the following source:

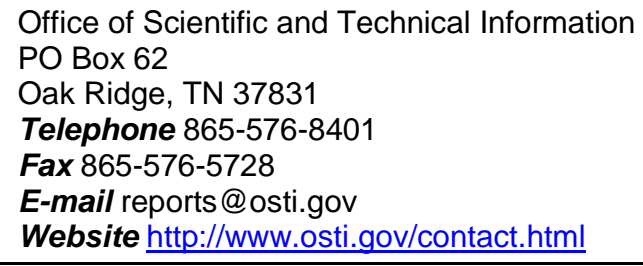

This report was prepared as an account of work sponsored by an agency of the United States Government. Neither the United States Government nor any agency thereof, nor any of their employees, makes any warranty, express or implied, or assumes any legal liability or responsibility for the accuracy, completeness, or usefulness of any information, apparatus, product, or process disclosed, or represents that its use would not infringe privately owned rights. Reference herein to any specific commercial product, process, or service by trade name, trademark, manufacturer, or otherwise, does not necessarily constitute or imply its endorsement, recommendation, or favoring by the United States Government or any agency thereof. The views and opinions of authors expressed herein do not necessarily state or reflect those of the United States Government or any agency thereof. 
Energy and Transportation Science Division

\title{
MEASUREMENT OF VEHICLE AIR CONDITIONING PULL-DOWN PERIOD
}

\author{
John F. Thomas \\ Shean P. Huff \\ Larry G. Moore \\ Brian H. West
}

Oak Ridge National Laboratory

Date Published: July 2016

Prepared by

OAK RIDGE NATIONAL LABORATORY

Oak Ridge, TN 37831-6283

managed by

UT-BATTELLE, LLC

for the

US DEPARTMENT OF ENERGY

under contract DE-AC05-00OR22725 



\section{CONTENTS}

Page

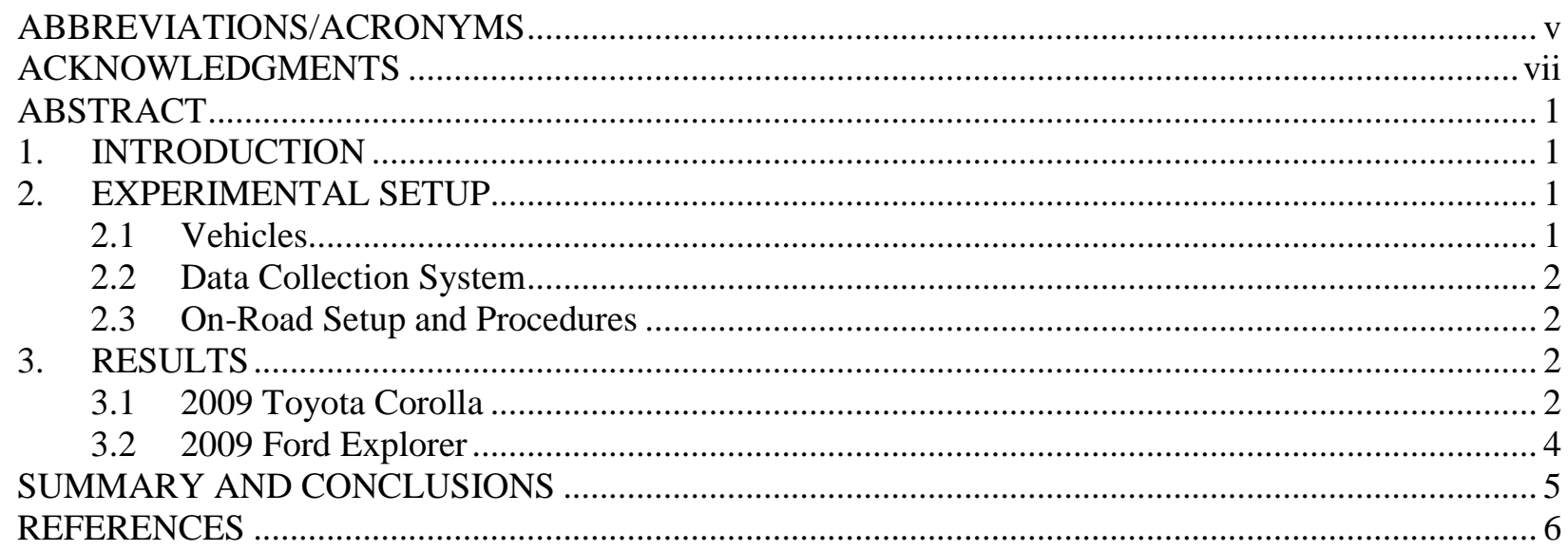




\section{ABBREVIATIONS/ACRONYMS}

$\begin{array}{ll}\text { A/C } & \text { air conditioning } \\ \text { Amb. } & \text { ambient } \\ \text { Avg. } & \text { average } \\ \text { ECT } & \text { engine coolant temperature } \\ { }^{\circ} \mathrm{F} & \text { degrees Fahrenheit } \\ \text { gal } & \text { gallon } \\ \text { h } & \text { hour } \\ \text { I4 } & \text { inline four cylinder configuration } \\ \text { mph } & \text { miles per hour } \\ \text { OBD-II } & \text { on-board diagnostic system II, mandated as standard in } 1996 \\ \text { s } & \text { second } \\ \text { TC } & \text { thermocouple } \\ \text { temp. } & \text { temperature } \\ \text { V6 } & \text { V-six cylinder configuration }\end{array}$




\section{ACKNOWLEDGMENTS}

The work described was sponsored by the U.S. Department of Energy (DOE) Office of Energy Efficiency and Renewable Energy, Vehicle Technologies Program. The authors gratefully acknowledge the support of Dennis Smith at DOE. Several Oak Ridge National Laboratory staff made important contributions to this work, including Bo Saulsbury, Bob Boundy, Robert Gibson, and Janet Hopson. 


\begin{abstract}
Air conditioner usage was characterized for high heat-load summer conditions during short driving trips using a 2009 Ford Explorer and a 2009 Toyota Corolla. Vehicles were parked in the sun with windows closed to allow the cabin to become hot. Experiments were conducted by entering the instrumented vehicles in this heated condition and driving on-road with the windows up and the air conditioning set to maximum cooling, maximum fan speed and the air flow setting to recirculate cabin air rather than pull in outside humid air. The main purpose was to determine the length of time the air conditioner system would remain at or very near maximum cooling power under these severe-duty conditions. Because of the variable and somewhat uncontrolled nature of the experiments, they serve only to show that for short vehicle trips, air conditioning can remain near or at full cooling capacity for 10-minutes or significantly longer and the cabin may be uncomfortably warm during much of this time.
\end{abstract}

\title{
1. INTRODUCTION
}

In a previous study [1] on-road and chassis dynamometer-based experiments with a 2009 Ford Explorer and a 2009 Toyota Corolla were conducted to assess fuel consumption penalties due to air conditioner $(\mathrm{A} / \mathrm{C})$ use at idle and highway cruise conditions. Experiments included these vehicles operating with various $\mathrm{A} / \mathrm{C}$ settings, with the $\mathrm{A} / \mathrm{C}$ off, and with $\mathrm{A} / \mathrm{C}$ off and windows open. The purpose was to better understand the actual fuel penalty due to $\mathrm{A} / \mathrm{C}$ use and fuel penalty trade-off between driving using the $\mathrm{A} / \mathrm{C}$ versus driving with the windows down [1]. A major portion of the previous effort involved running the $\mathrm{A} / \mathrm{C}$ at maximum cooling which generates the maximum fuel penalty; clearly the fuel penalty from $\mathrm{A} / \mathrm{C}$ usage is highly variable and dependent on many factors. Notable results from this previous study [1] included significant additional fuel use measured for $100 \% \mathrm{~A} / \mathrm{C}$ duty versus no use of climate control. Specifically this was $\sim 0.2 \mathrm{gal} / \mathrm{h}$ at idle to $\sim 0.4 \mathrm{gal} / \mathrm{h}$ at $40-70 \mathrm{mph}$ for the Explorer and $\sim 0.13$ $\mathrm{gal} / \mathrm{h}$ at idle and $\sim 0.17 \mathrm{gal} / \mathrm{h}$ at $40-70 \mathrm{mph}$ for the Corolla.

During peer review of the previous study, some reviewers questioned the usefulness of examining 100\% $\mathrm{A} / \mathrm{C}$ duty cycle, suggesting it would be unrealistically high. Obviously $100 \%$ duty cycle is the high endpoint of $\mathrm{A} / \mathrm{C}$ operation, and much $\mathrm{A} / \mathrm{C}$ use involves lower duty cycles. Prior to publication the reviewers did agree that $100 \%$ duty cycle was useful for the purposes of that particular study. This questioning inspired a modest follow-up effort to examine the pull-down interval, or the time that the A/C compressor remained fully engaged. It was hypothesized that it may be common for the $\mathrm{A} / \mathrm{C}$ to operate at maximum duty cycle for much of the time during short trips.

All of the authors' personal experience in summer driving would indicate $100 \%$ duty cycle is common, at least in regions with hot weather. A hot weather period was chosen to conduct experiments targeting measurement of how long A/C systems might operate at $100 \%$ duty cycle or at very high duty cycle. Because ORNL is situated in East Tennessee, hot and often humid weather occurs each summer.

\section{EXPERIMENTAL SETUP}

\subsection{VEHICLES}

The vehicles used were a 2009 Ford Explorer equipped with a 4.0 liter V6 engine and a five speed automatic transmission, and a 2009 Toyota Corolla with a 1.8 liter I4 engine and a four speed automatic transmission [1]. Both vehicles are equipped with cruise control which was used for some highway driving, and both vehicles were fueled with Halterman EEE-Lube Spec Certification Gasoline. 
Thermocouples (TCs) were placed in several locations to collect both ambient and A/C system conditions. The ambient temperature TC was located under the side view mirror in order to shield it from direct sunlight. TCs were placed in front of and behind the $\mathrm{A} / \mathrm{C}$ condenser to monitor the $\mathrm{A} / \mathrm{C}$ system heat rejection, and also in the center dash $\mathrm{A} / \mathrm{C}$ vent to monitor the temperature of the air exiting the $\mathrm{A} / \mathrm{C}$ system. Additionally, vehicle cabin temperature was monitored with a TC in the second row passenger area at a position representative of the approximate location of an adult passenger's head (commonly referred to as the breath temperature [2]).

Although no solar load was measured, it is noteworthy that the Explorer has a black exterior and interior, and was equipped with only moderate window tinting. The Corolla had a light gray exterior, a light gray interior, and minimal window tinting.

\subsection{DATA COLLECTION SYSTEM}

Data from each vehicle's data bus were collected using the OBD-II Interface and ScanXL Professional software from Palmer Performance Engineering (www.palmerperformance.com). With this system OBDII data including Vehicle Speed Sensor (VSS), Mass Air Flow (MAF), and Throttle Position Sensor (TPS) were collected. A diagnostics add-on capability applicable to the Ford vehicle was available from previous efforts [1] which monitored A/C clutch engagement via the OBD-II port. For the Toyota Corolla, A/C compressor status was monitored by measuring current to the magnetic clutch. The ambient and A/C system temperature data were collected using a USB TC-08 Thermocouple Data Logger from Pico Technology (www.picotech.com).

\subsection{ON-ROAD SETUP AND PROCEDURES}

The ORNL NTRC site is located in Knoxville and although straight and level stretches of highway are rare in this region, relatively flat roads and relatively flat sections of Interstate 75 were used for these experiments [1]. All experiments were completed during 8 test days over a 10 day hot-weather period. Vehicles were parked in the full mid-day sun in an unshaded parking lot. As expected, some variety in ambient conditions and vehicle initial conditions were observed during the experiments. Data were collected over two drive cycles, one to mimic city cycle driving and another for high-speed interstate driving, with most tests being the latter. These cycles were not consistent due to the changes in ambient and traffic conditions.

\section{RESULTS}

\subsection{TOYOTA COROLLA}

Four experiments were completed with the Corolla; three with mainly highway type driving and one with city type driving. The highway driving tests began with 1-3 minutes of low-speed stop-and-go driving until major roads were reached and highway driving was maintained. These experiments are summarized in Table 1. In all experiments A/C compressor duty cycle was virtually $100 \%$ for at least 15 minutes. The times given (in Table 1) are from the $\mathrm{A} / \mathrm{C}$ being turned on until the event described. The compressor command to operate stays on for a long initial period in all cases and even the shortest periods (7/17 and 7/19) were followed immediately by an extended "compressor on" period. Although the city cycle test on $7 / 17$ shows a large time ( 25 minutes) for the cabin to reach the chosen metric of $80^{\circ} \mathrm{F}$, it only took about 5 minutes to reach $85^{\circ} \mathrm{F}$. For this particular drive cycle, prolonged driving at $40 \mathrm{mph}$ from about 350 to 600 seconds was followed by more stop-and-go driving which reduced the engine speed, slowed the compressor speed and reduced air flow through the condenser (lowering A/C cooling capacity). There were no repeats of this individual test, therefore conclusions should be made with caution. Test $5 \mathrm{~b}$ shows 
the expected result that an $80{ }^{\circ} \mathrm{F}$ cabin temperature is reached sooner with a lower cabin starting temperature.

Averaged ambient wet bulb, dry bulb and dew point temperature are reported to document that the weather was hot with significant humidity. The average ambient temperature varies from the dry bulb temperature slightly because the dry and wet bulb temperatures were averaged over different time windows (for example, the wet bulb temperature was invalid during stops due to lack of air flow and this portion of time was excluded from averaging).

Table 1. Summary of pull down experimental results for the 2009 Toyota Corolla

\begin{tabular}{|c|c|c|c|c|c|c|c|c|}
\hline $\begin{array}{l}\text { Test Day, } \\
\text { Date }\end{array}$ & $\begin{array}{l}\text { City or } \\
\text { Highway } \\
\text { Driving }\end{array}$ & $\begin{array}{l}\text { Cabin } \\
\text { Start } \\
\text { Temp. } \\
\left({ }^{\circ} \mathrm{F}\right)\end{array}$ & $\begin{array}{l}\text { Avg. } \\
\text { Amb. } \\
\text { Temp. } \\
\left({ }^{\circ} \mathrm{F}\right)\end{array}$ & $\begin{array}{l}\text { Time Until } \\
\text { Compressor } \\
\text { First Cycles } \\
\text { Off } \\
\text { (s) }\end{array}$ & $\begin{array}{l}\text { Time to } \\
\text { Cabin } \\
\text { Reaching } \\
80^{\circ} \mathrm{F} \\
\text { (s) }\end{array}$ & $\begin{array}{c}\text { Ambient } \\
\text { Wet } \\
\text { Bulb } \\
\text { Temp. } \\
\left.\text { ( }{ }^{\circ} \mathrm{F}\right)\end{array}$ & $\begin{array}{c}\text { Ambient } \\
\text { Dry Bulb } \\
\text { Temp. } \\
\left({ }^{\circ} \mathrm{F}\right)\end{array}$ & $\begin{array}{c}\text { Ambient } \\
\text { Dew } \\
\text { Point } \\
\text { Temp. } \\
\left({ }^{\circ} \mathrm{F}\right)\end{array}$ \\
\hline $5 a, 7 / 16$ & $\mathrm{H}$ & 138 & 94 & 1500 & 500 & 74.5 & 94.2 & 65.6 \\
\hline $5 b, 7 / 16$ & $\mathrm{H}$ & 115 & 91 & 1480 & 230 & 76.1 & 91.1 & 70.0 \\
\hline $8,7 / 19$ & $\mathrm{H}$ & 138 & 94 & $440 *$ & 830 & 77.7 & 93.9 & 71.4 \\
\hline $6,7 / 17$ & $C$ & 136 & 98 & $760 *$ & 1500 & 76.4 & 98.6 & 70.0 \\
\hline
\end{tabular}

Measured results for experiment 5a are shown in Fig. 1. The first compressor-off event was observed when the vehicle stopped and then accelerated at about $1500 \mathrm{~s}$. Data review indicates that the compressor may be turned off briefly due to the engine state (hard acceleration) as well as cooling demand. For the $7 / 19$ case a near-stop is made at 440 seconds followed by a hard acceleration at which point the compressor cycled off briefly and then was $100 \%$ engaged for a long period. In all cases the concept that the $\mathrm{A} / \mathrm{C}$ stays at or near full-load for a short trip under common hot weather initial conditions is supported.

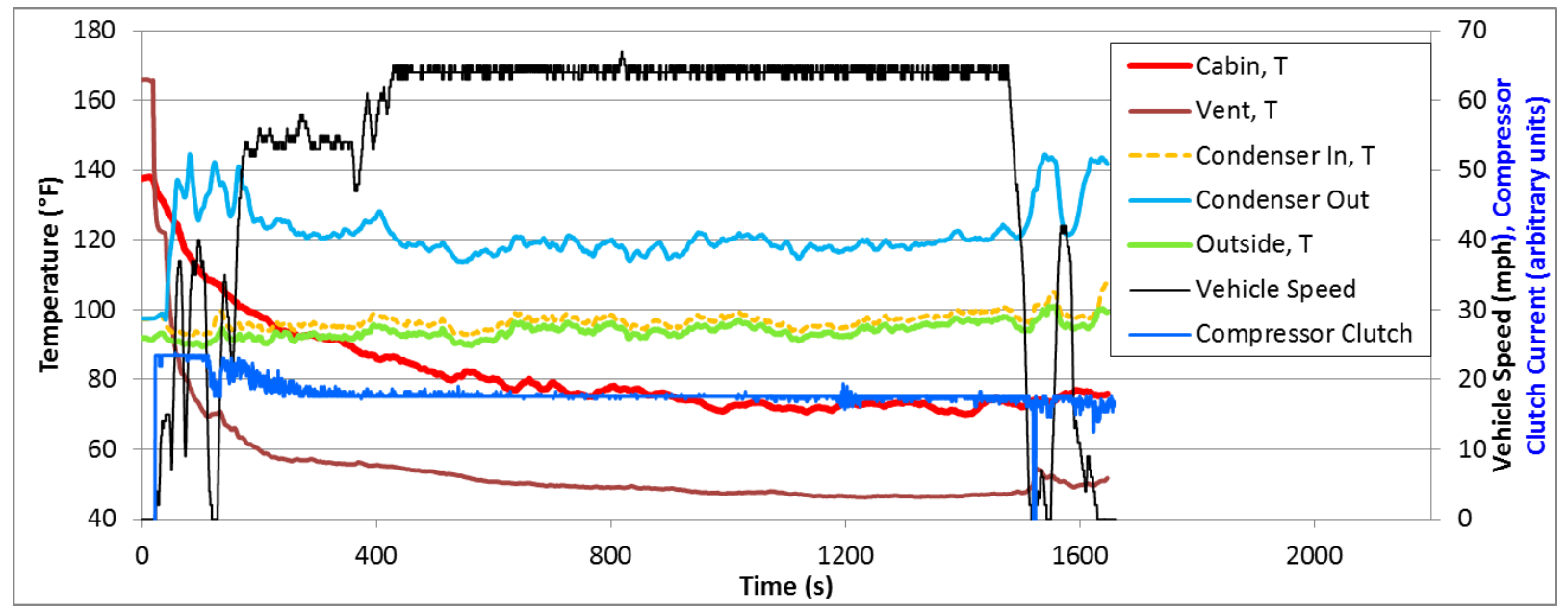

Figure 1. Results for Toyota Corolla pulldown experiment 5a. T=temperature. 


\subsection{FORD EXPLORER}

Nine experiments were completed with the Explorer, which are summarized in Table 2. Seven of the tests involved low-speed, stop and go driving for 1-3 minutes before reaching major roads at which point highway driving began. The two city driving tests involved mainly lower speed and stop and go driving. Examples of measured results from the Explorer experiments are shown in Figs. 2 and 3.

The major observation is that $\mathrm{A} / \mathrm{C}$ full cooling load is observed to continue for 7-23 minutes for this range of tests. It can also be seen that hotter initial conditions for the highway driving tests consistently show longer times until the compressor cycles. As expected, the city driving also appears to increase times for continuous or near-continuous compressor operation, perhaps because the average compressor speeds are lower and there is less cooling air flow through the condenser, both of which reduce the A/C cooling capacity. Because the city cycle was only performed twice, conclusions are made with caution. The high quality A/C clutch engagement data available for the Explorer allowed estimation of compressor on-time fraction later in each test when cycling on and off was established.

Table 2. Summary of pull down experimental results for the 2009 Ford Explorer

\begin{tabular}{|c|c|c|c|c|c|c|c|c|c|}
\hline $\begin{array}{l}\text { Test Day, } \\
\text { Date }\end{array}$ & $\begin{array}{l}\text { City or } \\
\text { Highway } \\
\text { Driving }\end{array}$ & $\begin{array}{l}\text { Cabin } \\
\text { Start } \\
\text { Temp. } \\
\left({ }^{\circ} \mathrm{F}\right) \\
\end{array}$ & $\begin{array}{l}\text { Avg. } \\
\text { Amb. } \\
\text { Temp. } \\
\left({ }^{\circ} \mathrm{F}\right)\end{array}$ & $\begin{array}{c}\text { Time Until } \\
\text { Compressor } \\
\text { First Cycles } \\
\text { Off } \\
\text { (s) }\end{array}$ & $\begin{array}{l}\text { Time to } \\
\text { Cabin } \\
\text { Reaching } \\
80^{\circ} \mathrm{F} \\
\text { (s) }\end{array}$ & $\begin{array}{c}\text { Compressor } \\
\text { On-time } \\
\text { Fraction } \\
\text { After } \\
\text { Cycling } \\
\text { Begins } \\
\end{array}$ & $\begin{array}{c}\text { Ambient } \\
\text { Wet } \\
\text { Bulb } \\
\text { Temp. } \\
\left({ }^{\circ} \mathrm{F}\right) \\
\end{array}$ & $\begin{array}{c}\text { Ambient } \\
\text { Dry Bulb } \\
\text { Temp. } \\
\left({ }^{\circ} \mathrm{F}\right)\end{array}$ & $\begin{array}{c}\text { Ambient } \\
\text { Dew } \\
\text { Point } \\
\text { Temp. } \\
\left({ }^{\circ} \mathrm{F}\right) \\
\end{array}$ \\
\hline $1,7 / 11$ & $\mathrm{H}$ & 128 & 88 & 600 & 1500 & $72 \%$ & 75.6 & 87.7 & 70.7 \\
\hline $4,7 / 15$ & $\mathrm{H}$ & 120 & 90 & 570 & 560 & $74 \%$ & 75.4 & 90.0 & 69.3 \\
\hline $5 a, 7 / 16$ & $\mathrm{H}$ & 132 & 94 & 960 & 940 & $90 \%$ & 79.3 & 93.8 & 74.0 \\
\hline $5 b, 7 / 16$ & $\mathrm{H}$ & 106.5 & 95 & 420 & 340 & $85 \%$ & 79.8 & 94.8 & 74.3 \\
\hline $6,7 / 17$ & $\mathrm{H}$ & 131 & 95 & 920 & 800 & $80 \%$ & 77.3 & 95.4 & 70.0 \\
\hline $7 a, 7 / 18$ & $\mathrm{H}$ & 139 & 95 & 970 & 1500 & $88 \%$ & 76.5 & 97.2 & 67.8 \\
\hline $7 b, 7 / 18$ & $\mathrm{H}$ & 114.5 & 93 & 490 & 490 & $83 \%$ & 74.3 & 92.9 & 66.1 \\
\hline $2,7 / 12$ & $C$ & 134 & 88 & 1400 & 1500 & $95 \%$ & 74.3 & 89.2 & 67.9 \\
\hline $3,7 / 13$ & C & 128 & 88 & 1010 & 860 & 91-95\% & 75.4 & 89.2 & 69.7 \\
\hline
\end{tabular}

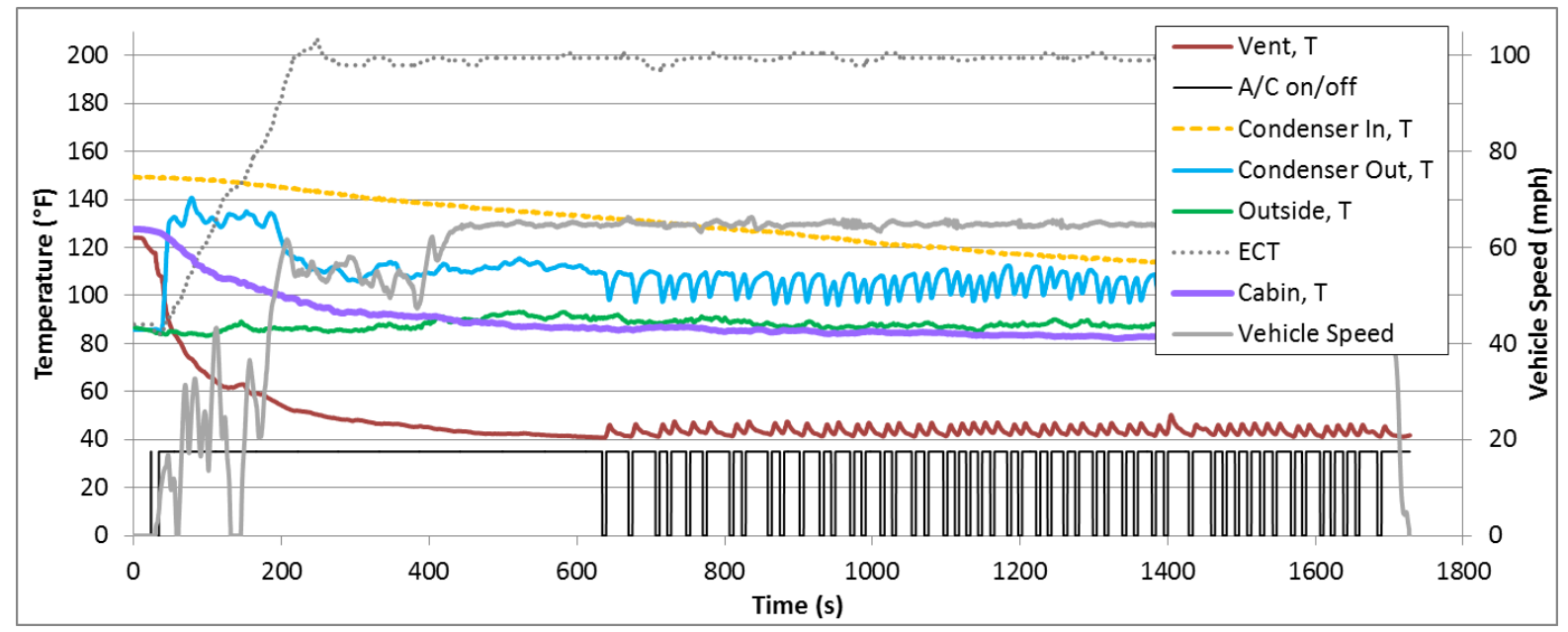

Figure 2. Results for Ford Explorer highway driving pulldown experiment $1 . \mathrm{T}=$ temperature, ECT $=$ engine coolant temperature. 


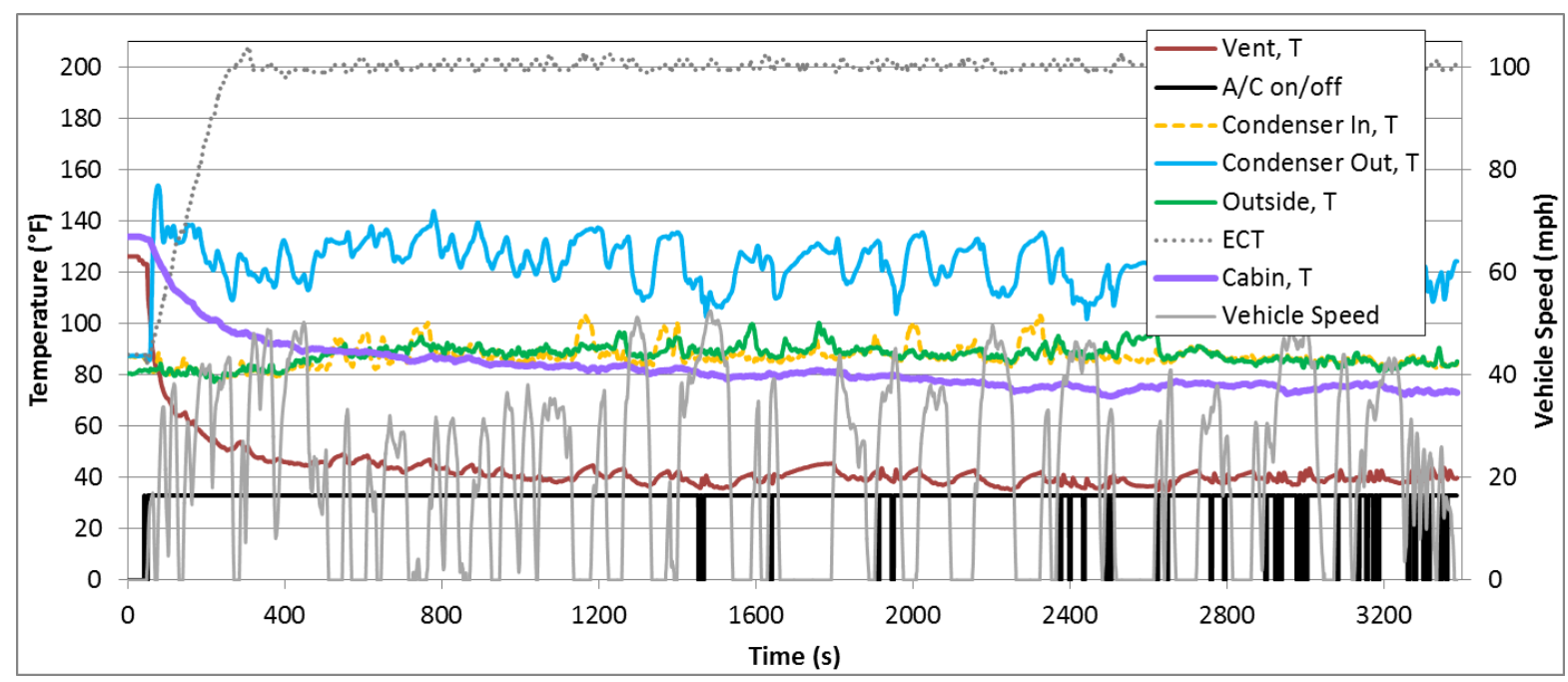

Figure 3. Results for Ford Explorer city driving pulldown experiment $2 . \mathrm{T}=$ temperature, ECT $=$ engine coolant temperature.

\section{SUMMARY AND CONCLUSIONS}

A model year 2009 sedan and SUV were parked in the full mid-day sun on hot summer days allowing the cabins to reach high temperatures, typical of unshaded parking conditions in hot weather. Researchers entered the vehicles and turned the $\mathrm{A} / \mathrm{C}$ systems to maximum cooling settings and then drove the vehicles to measure the time interval of $100 \% \mathrm{~A} / \mathrm{C}$ duty cycle.

- For the conditions tested, 7-25 minutes of $100 \%$ duty cycle was recorded for both vehicles.

- After compressor cycling began, compressor on-time remained at 66-95\% during the Explorer tests. Duty cycle is dependent on ambient conditions, driving cycle, etc.

- Pulldown of back seat temperature from $128-134^{\circ} \mathrm{F}$ initial temperature to $85^{\circ} \mathrm{F}$ generally took 8 12 minutes.

- For the broad range of conditions tested, it typically took 8-25 minutes for the cabin to reach $80^{\circ} \mathrm{F}$.

- From the previous study [1] the additional fuel use due to running the Ford Explorer A/C at 100\% duty cycle is $\sim 0.2 \mathrm{gal} / \mathrm{h}$ at idle (a $55 \%$ increase) and $\sim 0.4 \mathrm{gal} / \mathrm{h}$ at $40-70 \mathrm{mph}$ (an increase of $27 \%$ at $40 \mathrm{mph}$ and $14 \%$ at $70 \mathrm{mph}$ ). For the Toyota Corolla the incremental fuel consumption was $\sim 0.13 \mathrm{gal} / \mathrm{h}$ at idle $(60 \%$ increase) and $\sim 0.17 \mathrm{gal} / \mathrm{h}$ at $40-70 \mathrm{mph}$ (representing a $22 \%$ increase at $40 \mathrm{mph}$ to about a $9 \%$ increase at $70 \mathrm{mph}$ ).

- Pull-down period is dependent on initial conditions. Parking in the shade, opening the windows briefly before or at the start of the trip, and any other means to move the cabin temperature toward the desired set point will reduce the A/C compressor load and lower the fuel penalty. 


\section{REFERENCES}

1. S. Huff, B. West, J.F. Thomas, Effects of Air Conditioner Use on Real-World Fuel Economy, SAE Technical Paper 2013-01-0551, April, 2013. doi: 10.4271/2013-01-0551.

2. Rugh, J., Hendricks, T., and Koram, K., "Effect of Solar Reflective Glazing on Ford Explorer ClimateControl, Fuel Economy, and Emissions," SAE Technical Paper 2001-01-3077, 2001, doi:10.4271/2001-01-3077. 